Chapter 13

\title{
Biodegradation of Nitrogen in a Commercial Recirculating Aquaculture Facility
}

\author{
S. Sandu and E. Hallerman \\ Additional information is available at the end of the chapter \\ http://dx.doi.org/10.5772/55841
}

\section{Introduction}

\subsection{Need for biodegradation of nitrogen species in aquaculture systems}

Commercial production of fish involves high levels of feeding. While digestive breakdown of lipids and carbohydrates yields water and carbon dioxide as waste products, digestion of proteins also yields nitrogenous compounds. In teleost (i.e., bony) fishes, these nitrogenous wastes are excreted predominately as ammonia. Total ammonia-nitrogen (TAN) consists of ionized ammonia $\left(\mathrm{NH}_{4}{ }^{+} \mathrm{N}\right)$ and un-ionized ammonia $\left(\mathrm{NH}_{3}-\mathrm{N}\right)$, the latter of which can prove toxic to fish. The fraction of TAN in the unionized form is dependent upon the $\mathrm{pH}$ and temperature of the water (Losordo 1997, Lekang 2007) and to a lesser degree its salinity (Diaz et al. 2012). At pH values less than 7.5, most ammonia is in the ionized form, and high levels of TAN can be tolerated. At higher $\mathrm{pH}$, however, levels of un-ionized ammonia become problematic. Hence, biodegradation of ammonia is critical for the success of fish culture. Nitrifying bacteria, including Nitrosomonas sp., utilize $\mathrm{NH}_{3}-\mathrm{N}$ as the energy source for growth, producing nitrite, $\mathrm{NO}_{2}-\mathrm{N}$. While nitrite-nitrogen is not as toxic as un-ionized ammonianitrogen, it can prove harmful to fish. The most common mode of toxicity is anoxia, as nitritenitrogen crosses the gills into the circulatory system and converts hemoglobin to methemoglobin, rendering it unable to bind and transport oxygen to the tissues (Palachek and Tomasso 1984, Svobodova et al. 2005). Other nitrifying bacteria, including Nitrobacter sp., utilize nitrite as their energy source, producing nitrate, $\mathrm{NO}_{3}-\mathrm{N}$. Nitrate-nitrogen concentrations are not generally of concern to aquaculturists, as most species can tolerate levels as high as $200 \mathrm{mg} / \mathrm{L}$ (Russo and Thurston 1991). Nitrate rarely reaches such high levels, as it is removed from the system by water exchanges and by passive denitrification in anaerobic pockets within the production or filtration systems (van Rijn 1996, Tal et al. 2006) or in denitrification reactors (Hamlin et al. 2008, Sandu et al. 2011). 
Controlled degradation of nitrogenous wastes in filtration units is a major consideration in design and operation of commercial recirculating aquaculture systems. Among the technologies available (Crab et al. 2007), biological filtration is most commonly used. Biological filters are designed to provide abundant surface area for the attachment of complex microbial communities (Schreier et al. 2010) rich in Nitrosomonas and Nitrobacter species (Chen et al. 2006, Itoi et al. 2007, van Kessel et al. 2010). The nitrification capacity of the water treatment system is often the factor that limits production in a recirculating aquaculture system (Lemarie et al. 2004, Eschar et al. 2006, Diaz et al. 2012).

\subsection{Utility of a nitrogen budget}

The production efficiency of an aquaculture system can be evaluated through analysis of the conversion of nitrogen to fish biomass and to biodegradation pathways (Thoman et al. 2001). Nitrogen dynamics can be quantified by a mass balance equation, most simply as the difference between nitrogen in the feed supply and nutrients subsequently fixed as fish biomass. A nitrogen budget can quantify nitrogen fixation in fish biomass at various fish stocking densities (Suresh and Kwei 1992; Siddiqui and Al-Harbi 1999), nutrient release into the water column as dissolved and particulate excretion of fish (Krom and Neori 1989), and deposition of nitrogen into pond sediment (Acosta-Nassar et al. 1994). By estimating total nitrogen budgets for a particular species and culture system, we can evaluate the efficacy of water treatment processes (Porter et al. 1987). Hence, a nitrogen budget provides information crucial for the design and optimization of a production system, feeding strategies, and water and effluent treatment processes.

\subsection{Biodegradation of nitrogenous wastes in a tilapia production system}

Blue Ridge Aquaculture (BRA) in Martinsville, Virginia, USA is a large commercial facility that produces 1300 metric tons of hybrid tilapia Oreochromis sp. per year. To our knowledge, it is the largest recirculating aquaculture facility in existence. Before our study, little information existed about nitrogen budgets in commercial-scale fish production facilities, especially those using freshwater recirculating systems. By deriving a nitrogen budget, we can quantify the forms and proportions of nitrogen ingested as food as it becomes bound in tilapia biomass, excreted as metabolites, biodegraded by microorganisms, lost as gas by denitrification, or released in effluent. Knowledge of the nitrogen budget can help optimize operations, improving facility efficiency and maximizing production. Using Blue Ridge Aquaculture as our study system, our objectives were to: (1) examine nitrogen dynamics for the grow-out systems, (2) relate the nitrogen budget to water quality, (3) evaluate biofilter loading and nitrogen removal efficiency, and (4) predict maximum system carrying capacity. All abbreviations used in this chapter are shown in Table 1.

$a=$ mole fraction of unionized ammonia nitrogen (decimal fraction)

$A C R=$ areal conversion rate $\left(\mathrm{mg} / \mathrm{m}^{2}-\mathrm{d}\right)$

$A_{\mathrm{NH3}-\mathrm{N}}=$ concentration of unionized ammonia nitrogen $(\mathrm{mg} / \mathrm{L})$ 
$A_{\text {TAN }}=$ maximum allowable concentration of total ammonia nitrogen ( $\left.\mathrm{mg} / \mathrm{L}\right)$

$\mathrm{BRA}=$ Blue Ridge Aquaculture

$\mathrm{C}_{\text {TAN }}=$ total ammonia nitrogen concentration in fish tank $(\mathrm{mg} / \mathrm{L})$

$\mathrm{C}_{\text {TANe }}=$ total ammonia nitrogen concentration in the effluent from filters ( $\mathrm{mg} / \mathrm{L}$ )

$\mathrm{C}_{\text {TANi }}=$ total ammonia nitrogen concentration in the supply water $(\mathrm{mg} / \mathrm{L})$

$E_{a}=$ efficiency of rotating biological contactor for removal of ammonia nitrogen (percent)

$F A=$ amount of feed $(\mathrm{kg})$

$F B=$ fish biomass $(\mathrm{kg})$

$F C=$ feed conversion factor (decimal fraction)

$F P=$ protein content of feed (decimal fraction)

$F R_{\text {MTAN }}=$ maximum feeding rate $(\mathrm{kg} / \mathrm{d})$

$L C 50=$ lethal concentration of a compound to $50 \%$ of the individuals in a population

$L N=$ nitrogen load ( $\mathrm{g} \mathrm{N} / \mathrm{kg}$ fish produced)

$L_{\text {TAN }}=$ ammonia loading ( $\left.\mathrm{g} / \mathrm{hr}\right)$

$N_{\text {DENIT }}=$ nitrogen gas removed by denitrification $(\mathrm{mg} / \mathrm{L})$

$N_{\text {DIN }}=$ dissolved inorganic nitrogen $(\mathrm{mg} / \mathrm{L})$

$N_{\text {feed }}=$ nitrogen fixed in feed $(\mathrm{g} / \mathrm{kg}$ feed)

$N_{\text {fish }}=$ nitrogen fixed in fish $(\mathrm{g} / \mathrm{kg}$ fish produced)

$N_{\text {mort }}=$ nitrogen fixed in dead fish ( $\mathrm{g} / \mathrm{kg}$ fish removed)

$\mathrm{N}_{\mathrm{NO} 2}{ }^{-}=$nitrite nitrogen $(\mathrm{mg} / \mathrm{L})$

$\mathrm{N}_{\mathrm{NO} 3}{ }^{-}=$nitrate nitrogen $(\mathrm{mg} / \mathrm{L})$

$N_{\mathrm{NH} 3 \mathrm{vol}}=$ nitrogen removed by ammonia volatilization $(\mathrm{mg} / \mathrm{L})$

$\mathrm{NO}_{3}-N_{\text {pass }}=$ nitrate removed passively by denitrification $(\mathrm{mg} / \mathrm{L})$

$\mathrm{NO}_{3}-N_{\text {exch }}=$ nitrate removed by exchange of water $(\mathrm{mg} / \mathrm{L})$

$N_{\text {TAN }}=$ total ammonia nitrogen $(\mathrm{mg} / \mathrm{L})$

$N_{\text {TON }}=$ total organic nitrogen $(\mathrm{mg} / \mathrm{L})$

$P C=$ protein content of feed (decimal fraction)

$P_{\text {NO3-N }}=$ partitioning of nitrate nitrogen $(\mathrm{g} / \mathrm{kg})$

$P_{\text {TAN }}=$ production rate of ammonia nitrogen $(\mathrm{g} / \mathrm{kg})$

$Q=$ flow rate through system $\left(\mathrm{m}^{3} / \mathrm{min}\right.$ or $\left.\mathrm{L} / \mathrm{h}\right)$

$Q_{f}=$ recirculation flow rate $\left(\mathrm{m}^{3} / \mathrm{min}\right.$ or $\left.\mathrm{L} / \mathrm{h}\right)$

RAS = recirculating aquaculture system

$R_{\text {TAN }}=$ ammonia removal rate $(\mathrm{g} / \mathrm{h})$

$S=$ surface area $\left(\mathrm{m}^{2}\right)$ 


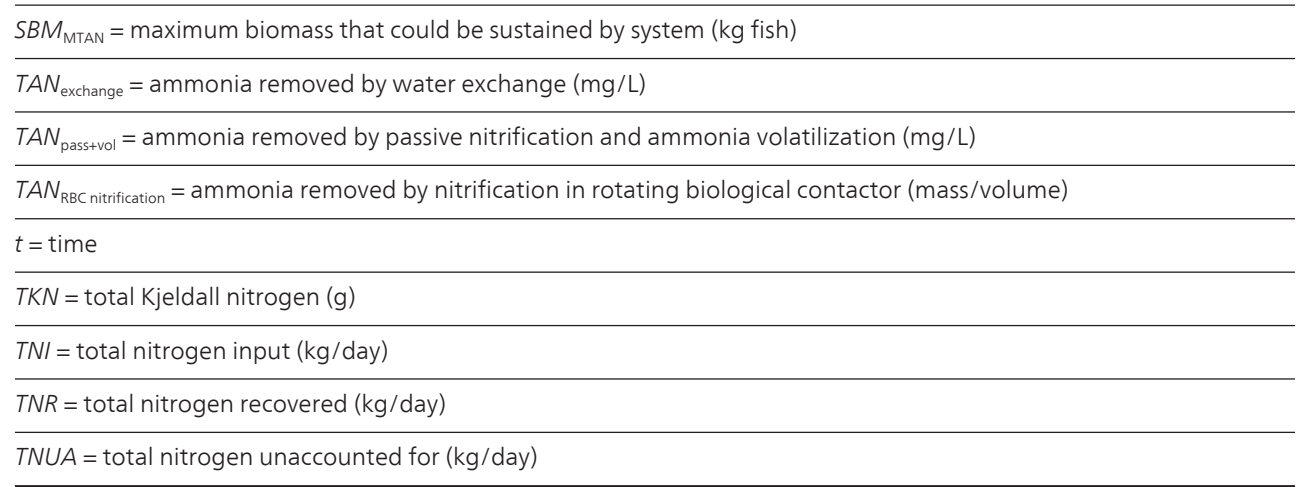

Table 1. Abbreviations and associated units.

Tilapias are a group of fishes of great importance to world aquaculture (Costa-Pierce and Rakocy 1997, Fitzsimmons 1997, Lim and Webster 2006). Tilapias adapt readily to a range of production systems ranging from traditional extensive pond systems to high-input intensive pond systems to super-intensive recirculating aquaculture systems. Like all fishes, tilapias are sensitive to concentrations of nitrogenous wastes. The 48 -hour $\mathrm{LC}_{50}$ value for $\mathrm{NH}_{3}$ for Jordan tilapia Oreochromis aureus was $2.40 \mathrm{mg} / \mathrm{L}$ (Redner and Stickney 1979). The 48-hour LC L0 $_{\text {value }}$ for hybrid red tilapia O. mossambicus $x$ O. niloticus fry was $6.6 \mathrm{mg} / \mathrm{L}$ (Daud et al. 1988), although the threshold lethal concentration was $0.24 \mathrm{mg} / \mathrm{L}$. The 24 -hour LC $_{50}$ value for un-ionized ammonia for O. niloticus was $1.46 \mathrm{mg} / \mathrm{L}$ (Evans et al. 2006) Sublethal effects of $\mathrm{NH}_{3}-\mathrm{N}$ include tissue damage, decreased growth, increased feed conversion ratio, acute stress response, increased disease susceptibility, and reduced reproductive capacity (Russo and Thurston 1991, Yildiz et al. 2006, El-Sherif and El-Feky 2008, Benli et al. 2008). Tilapias also exhibit sensitivity to elevated nitrite concentrations. The 96-hour $\mathrm{LC}_{50}$ for nitrite-nitrogen for $O$. aureus was $16.2 \mathrm{mg} / \mathrm{L}$ at pH 7.2 and $22 \mathrm{mg} / \mathrm{L}$ chloride (Palachek and Tomasso 1984). Acute nitrite toxicity for O. niloticus varied with chloride levels and with fish size, with smaller fish proving more tolerant (Atwood et al. 2001, Wang et al. 2006). Nitrite-nitrogen levels should be kept below $5 \mathrm{mg} / \mathrm{L}$ within tilapia culture vessels (Losordo 1997). Knowledge of these toxicity values is useful for setting criteria for the design or evaluating the performance of filters for biodegradation of nitrogenous wastes in aquaculture systems.

\section{Methods}

\subsection{Culture systems}

The BRA facility includes systems for broodstock holding, fish breeding, egg incubation/ hatching, fingerling rearing, and food-fish production. The main building houses 42 recirculating aquaculture systems for grow-out to market size (Figure 1) that were the focus of our study. Each grow-out system (Figure 2) includes a fish production tank, a sedimentation basin 
for solids removal, a rotating biological contactor (RBC) for microbial biodegradation including nitrification, and an oxygenation unit. Each fish production system is rectangular in shape, built from concrete, holds $215 \mathrm{~m}^{3}$ of water, and consists of a fish-rearing tank $\left(119 \mathrm{~m}^{3}\right)$, a multitube clarifier sedimentation basin $\left(37 \mathrm{~m}^{3}\right)$, an air-driven rotating biological contactor $\left(59 \mathrm{~m}^{3}\right.$ basin volume, 13,366 $\mathrm{m}^{2}$ surface area per shaft), and an underground U-tube oxygenation system. The total volume of the grow-out unit is $9030 \mathrm{~m}^{3}$. The water surface is at the same level in the fish tank, sedimentation and RBC compartments, and water passes freely from one section into another through large pipes or apertures. A pump receives water from the rotating biological contactor compartment and pushes it through U-tubes and then to the far end of the fish production tank, driving the recirculation. The filtration rate is $3.8 \mathrm{~m}^{3} / \mathrm{min}$, and the system turnover time is about once per hour.

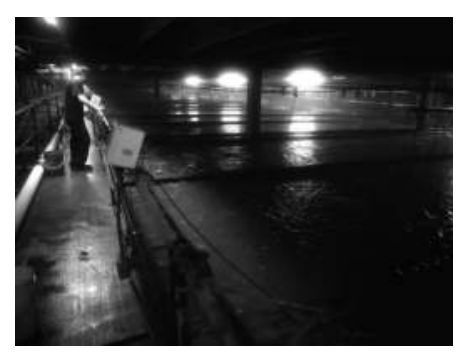

Figure 1. Commercial-scale tilapia grow-out systems at Blue Ridge Aquaculture. The grow-out units are to the right of the catwalk and sedimentation basins to the left. Photograph courtesy of Blue Ridge Aquaculture.

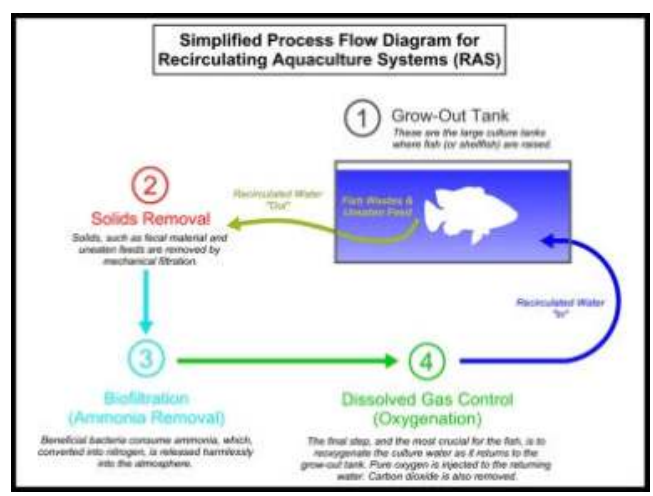

(A)

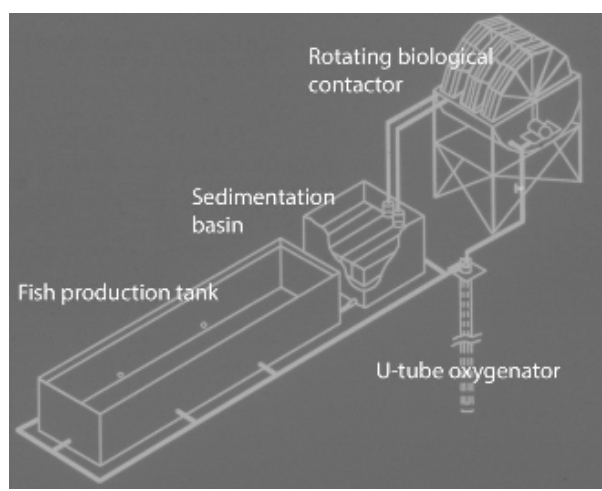

(B)

Figure 2. A) Conceptual diagram and (B) and engineering drawing of a single recirculating tilapia grow-out system at Blue Ridge Aquaculture. Diagram courtesy of Blue Ridge Aquaculture.

BRA practices partial water exchange daily for controlling solids, dissolved organics and nutrient accumulation in fish grow-out tanks. Water is exchanged daily from the system in the 
interval between 2:00 p.m. and 8:00 a.m. Management practice is to completely flush the sedimentation basin after each instance that 227 kilograms of feed has been administered to a particular production unit. The exchange rate averages $22.3 \%$ per day, but the daily percentage varies among production units as a function of the size of fish, water quality requirements, and the amount of feed delivered to the system. The exchange water originates from wells, and is supplemented with municipal tap water when necessary. Exchange water replaces that used to remove settled particulate material, and thereby dilutes dissolved organic materials, dissolved nutrients, and salts.

Fish are fed commercially-prepared pelleted diets containing 36 or $40 \%$ minimum crude protein and $8-16 \%$ lipid levels, varying with the age of the fish. The feed is distributed hourly to the tanks over the 24-hour period. Fish production is managed so that 21-27 metric tons of $600-\mathrm{g}$ fish reaches marketable size each week for shipment to a live market.

\subsection{System boundaries}

For the purpose of this study, the 42 recirculating aquaculture systems for grow-out were delimited as a unique system for purposes of quantifying the nitrogen budget. In certain contexts as set out below, $\mathrm{N}$ dynamics were quantified in greater detail in four individual systems. Broodstock holding and spawning facilities, a hatchery, and two greenhouses for fingerling production contain only a small part of the facility fish biomass, volume and exchange flow (i.e., they handle $3.0 \%$ of the fish biomass and $4.4 \%$ of the total nitrogen input). Because of their small contribution, the nitrogen budgets for these systems are not presented here, but can be found in Sandu (2004).

\subsection{Inputs, outputs and nitrogen pools}

The nitrogen budget is expressed as a mass-balance equation of all nitrogen forms, with total inputs plus generation equal to total outputs plus consumption. We found no measurable amounts of dissolved inorganic nitrogen in the replacement water. Hence, feed provided to fish was the sole nitrogen source in the form of organic nitrogen $\left(N_{\text {feed }}\right)$. Multiplication of $N_{\text {feed }}$ by the total amount of feed provided the mass of total nitrogen input (TNI). The nitrogen budget was accounted for in five known pools:

1. Nitrogen fixed in fish biomass as organic nitrogen, $N_{\text {fish }}$

2. Nitrogen fixed in dead fish biomass as organic nitrogen, $N_{\text {mort }}$

3. Dissolved inorganic nitrogen, $N_{\mathrm{DIN}}$, which included $N_{\mathrm{TAN}}, N_{\mathrm{NO} 2}$, and $N_{\mathrm{NO} 3}$,

4. Total organic nitrogen in effluent, $N_{\mathrm{TON}}$, and

5. Nitrogen gas removed from the system by passive denitrification, $N_{\text {denit }}$ and by ammonia volatilization, $N_{\mathrm{NH} 3 \mathrm{vol}}$.

All transformations among pools were assumed to be in a dynamic equilibrium over a defined period of time. We accounted for the mass fractions of nitrogen from Pools 1 to 4 (i.e., the measurable pools) as total nitrogen recovered (TNR), while the difference between total 
nitrogen input and total nitrogen recovered constituted pool 5, the mass fraction of total nitrogen unaccounted for (TNUA).

\subsection{Analytical techniques}

Analyses of fish and of feed for protein content followed Thiex et al. (2002), who indicated that by dry weight, $16 \%$ of protein is nitrogen. Samples were processed at the Forage Testing Laboratory, Virginia Polytechnic Institute and State University, Blacksburg, Virginia. Analyses for inorganic dissolved nitrogen forms ( $\mathrm{TAN}, \mathrm{NO}_{2}^{-}-\mathrm{N}$, and $\mathrm{NO}_{3}^{-}-\mathrm{N}$ ) were conducted on site using a Hach DR2400 spectrophotometer (Hach Company, Loveland, Colorado). Total Kjeldall nitrogen (TKN) was determined using macro-Kjeldall Standard Method $4500-\mathrm{N}_{\text {org }}$ B (APHA et al., 1998). Samples were acidified below pH 2 using $\mathrm{H}_{2} \mathrm{SO}_{4}$, refrigerated with ice, and transported to the Department of Civil and Environmental Engineering at Virginia Polytechnic Institute and State University, Blacksburg, Virginia, for analysis. Temperature and $\mathrm{pH}$ were measured directly on site using an Acorn Meter (Kit Model pH 6, Oakton, Vernon Hills, Illinois). Alkalinity was determined on-site using the Hach Permachem ${ }^{\circledR}$ Method. Dissolved oxygen (DO) was measured using a YSI (Model 550, Yellow Springs, Ohio) instrument. We calculated total organic nitrogen as the difference between TKN and total ammonia nitrogen (TAN).

\subsection{Nitrogen budget determination}

Under steady-state conditions, fish biomass does not fluctuate significantly over time (i.e., harvest equals growth), and the daily rations of feed are constant. Under these assumptions, we derived the nitrogen budget by determining the nitrogen input with feed and the output of nitrogenous compounds in known pools. We quantified daily amounts of nitrogen in feed, fish, and mortalities using information on feed consumption, fish production, and mortalities provided by BRA management. We measured the components of dissolved inorganic nitrogen and total organic nitrogen pools directly. We extrapolated mean values to the entire exchange volume from a day to determine the mass of nitrogen recovered in these forms. We assumed that the amount of nitrogen missing from the balance was lost by passive denitrification and by ammonia volatilization.

We considered both types of feed used in the system (with $36 \%$ or $40 \%$ standard protein content) to determine nitrogen fixed in feed, $N_{\text {feed }}$. We collected samples from three different points in storage silos for nitrogen content determination. We calculated $N_{\text {feed }}$ as a composite using the equation:

$$
N_{\text {feed }}=\Sigma(F A \times P C \times 0.16)
$$

where $F A=$ amount of feed, $P C=$ protein content of the feed, and $0.16=$ concentration of nitrogen in protein (Thiex et al. 2002). We determined PC by laboratory analyses because protein content may differ from that claimed by the feed producer. We obtained the total mass of nitrogen originating from the feed input, TNI, by multiplying $N_{\text {feed }}$ by the amount fed, FA. 
To determine fixation of nitrogen in fish, $N_{\text {fish }}$ we analyzed protein content in triplicate samples of muscle tissue from fish from three size-classes. We estimated the proportions of fish in each size-class as 5\% juveniles (i.e., newly introduced to the system from the hatchery), $60 \%$ intermediate, and 35\% marketable size. With data on protein content of each fish size-class, we determined $N_{\text {fish }}$ as a composite using the equation:

$$
N_{\text {fish }}=\Sigma(F B \times F P \times 0.16)
$$

where $F B=$ biomass of fish, and $F P=$ protein content of the fish.

About $3.5 \%$ of the fish production (by number) was lost as mortalities. We assumed that nitrogen fixed in dead fish, $N_{\text {mort }}$ had the same nitrogen content as $N_{\text {fish. }}$. In order to determine the biomass of $N_{\text {mort }}$, we collected mortalities daily from the production system for a two-week period, sorted them by size, and weighed them. We used these data to determine $N_{\text {mort }}$ using equation 2.

Nitrogen load, $L_{N}$, entered the water column as ammonia and as organic nitrogen bound in feces. We quantified $L_{N}$ as all nitrogen from feed that was not accounted for as living or dead fish as using the equation:

$$
L_{N}=\left[N_{\text {feed }}-\left(N_{\text {fish }}+N_{\text {mort }}\right)\right] / F B
$$

Hence, $L_{\mathrm{N}}$ quantified the amount of nitrogen that sustained the nitrogen cycle throughout the system, supplying all effluent nitrogen pools.

We quantified total organic nitrogen as the difference between TKN and TAN from the effluent. We obtained values for TKN, TAN, $\mathrm{NO}_{2}{ }^{--} \mathrm{N}$, and $\mathrm{NO}_{3}{ }^{-}-\mathrm{N}$ by analyzing seven samples collected from the effluent discharge pipe at 3-hour intervals between 2:00 p.m. and 8:00 a.m. because effluent originated from the production system only during that interval. We repeated the tests twice (on different days) and averaged the results. We estimated daily production of these nitrogen forms by multiplying the average concentration $(\mathrm{mg} / \mathrm{L})$ by the volume of wastewater released from the system during a one-day period.

All nitrogen in feed that was not recovered as living or dead fish or as total organic nitrogen represented the dissolved inorganic fraction that entered the water as TAN. Hence, we determined ammonia production as:

$$
P_{\text {TAN }}=N_{\text {feed }}-\left(N_{\text {fish }}+N_{\text {mort }}+N_{\text {TON }}\right) / F A
$$

The sum of $\mathrm{TAN}, \mathrm{NO}_{2}{ }^{-} \mathrm{N}$, and $\mathrm{NO}_{3}^{-}-\mathrm{N}$ found in the effluent represented the fraction of nitrogen recovered as dissolved inorganic nitrogen, $N_{D I N}$. The summation of $N_{D I N}, N_{\text {fish }}, N_{\text {mort }}$ and $N_{\text {TON }}$ provided the value for total nitrogen recovered, TNR. We determined total nitrogen unac- 
counted for, TNUA, by subtracting total nitrogen recovered, TNR, from total nitrogen input, TNI.

\subsection{RAS carrying capacity, $\mathrm{RBC}$ design, $\mathrm{TAN}$ and $\mathrm{NO}_{3}^{-}-\mathrm{N}$ removal}

We used a simplified version of a model proposed by Losordo and Westers (1994) to determine the carrying capacity of the production system; that is, we considered only the parts of the model concerning maximum system carrying capacity with respect to TAN. Modeling of the flow rate through biofilters was unnecessary because the flow rate was fixed among all recirculating aquaculture systems at $3.78 \mathrm{~m}^{3} / \mathrm{min}$.

Four recirculating aquaculture systems chosen for intensive study held different age-groups of fish from juvenile to marketable size in order to represent the overall population in the facility. We knew total fish biomass, fish size, feeding rate, crude protein content of feed, daily percent body weight fed, flow rate through the system, and daily rate of exchange for each selected system. We measured other parameters, such as TAN, $\mathrm{NO}_{3}^{-}-\mathrm{N}, \mathrm{NO}_{2}^{-}-\mathrm{N}, \mathrm{pH}$, temperature, and dissolved oxygen, using standard methods (APHA et al., 1998). We performed these analyses on composite samples collected from the fish-rearing tanks or from the rotating biological contactor's influent and effluent at four-hour intervals. By sampling from appropriate locations, we determined the effects of fish tanks, biofilters or sedimentation basins on each parameter. The experiments extended between consecutive water exchanges. We scaled the data to 24-hour intervals and determined mean and variance for each water quality parameter.

We determined the maximum system carrying capacity with respect to TAN as follows. We calculated the maximum allowable TAN concentration, $A_{\mathrm{TAN}}$ as:

$$
A_{\mathrm{TAN}}=A_{\mathrm{NH} 3-\mathrm{N}} / \mathrm{a}
$$

where $a=$ the mole fraction of unionized ammonia nitrogen as determined by $\mathrm{pH}$ and temperature (Huguenin and Colt, 1989). We calculated maximum feed rate, $F R_{\mathrm{mTAN}}$ by assuming that the TAN concentration of a fish tank equals $A_{\mathrm{TAN}}$ as:

$$
F R_{\text {mTAN }}=\left[A_{T A N} x Q_{f} \times E_{a}+Q\left(C_{T A N}-C_{T A N i}\right)\right] /(0.092 \times P C)
$$

where $Q_{f}=$ the recirculating flow rate, or flow rate to the RBC, known to be $227,100 \mathrm{~L} / \mathrm{hr}$, and $0.092=$ model constant coefficient. We determined the efficiency of the rotating biological contactor for removal of ammonia nitrogen, $E_{\mathrm{a}}$ as:

$$
E_{\mathrm{a}}=\left[\left(C_{\text {TAN }}-C_{\text {TANe }}\right) / C_{\text {TAN }}\right] \times 100
$$

We estimated the maximum biomass that could be sustained within the system, $S B M_{\text {mTAN }}$ as: 


$$
S B M_{\mathrm{mTAN}}=F R_{\mathrm{mTAN}} / \% B W
$$

where $\% B W=$ the feeding rate, expressed as a percent of body weight per day.

$P_{\text {TAN }}$ is the rate of production of TAN in the system by metabolism of fish and microbial degradation of uneaten feed. We estimated $P_{T A N}$ as a function of the feed rate and the percentage of protein in feed:

$$
P_{\text {TAN }}=\left(F A^{*} P C^{*} 0.102\right) / t
$$

where $t=$ the period of time from the onset of feeding to the next feeding.

This equation is based on the following assumptions and empirical estimates:

a. $16 \%$ of feed protein is nitrogen,

b. $80 \%$ of the nitrogen is assimilated,

c. unassimilated nitrogen in fecal matter is removed rapidly from the tank,

d. $80 \%$ of assimilated nitrogen is excreted, and

e. all of the TAN is excreted during $t$ hours.

The coefficient 0.102 represents the product of values suggested by assumptions $a$ through $d$ (i.e., $0.16 \times 0.8 \times 0.8=0.102$ ).

We determined the mass flow rate of TAN to a rotating biological contactor, or ammonia loading, $L_{\text {TAN }}$, from known $\left(Q_{\mathrm{f}}\right)$ and experimentally determined $\left(C_{\text {TAN } f}\right)$ parameters as:

$$
L_{T A N}=Q_{f} \times C_{T A N f}
$$

We determined the ammonia removal rate, $R_{\mathrm{TAN}}$, as:

$$
R_{\text {TAN }}=\left(C_{\text {TANf }}-C_{\text {TANe }}\right) \times Q_{f}
$$

The fraction $\left(R_{\mathrm{TAN}} \times 100\right) / P_{\mathrm{TAN}}$ represents the percentage of TAN that was removed by means other than the rotating biological contactor.

We estimated the nitrification performance of a rotating biological contactor as areal conversion rate, $A C R$, representing the amount of TAN oxidized by a unit of surface area in 24 hours:

$$
A C R=R_{\mathrm{TAN}} / S
$$


where $S$, the surface area of an RBC, was $13,336 \mathrm{~m}^{2}$.

The mass balance quantifying the partitioning of $P_{\text {TAN }}$ removal was:

$$
P_{\text {TAN }}=T A N_{\text {pass }+ \text { vol }}+T A N_{\text {RBC nitrification. }}+T A N_{\text {exchange }}
$$

We used a similar approach to determine $\mathrm{NO}_{3}^{-}-\mathrm{N}$ partitioning using the equation:

$$
P_{\mathrm{NO} 3}{ }_{-\mathrm{N}}^{-}=\mathrm{NO}_{3}{ }^{-}-\mathrm{N}_{\text {pass. }}+\mathrm{NO}_{3}^{-}-\mathrm{N}_{\text {exch }}
$$

\subsection{Statistical analysis}

We used linear regressions to determine the relationship between daily TAN production $\left(P_{\text {TAN }}\right)$ and TAN removal efficiency per pass $\left(E_{a}\right)$, and between fish biomass and percent $P_{\text {TAN }}$ transformed by passive denitrification in the four systems tested.

\section{Results}

\subsection{Nitrogen budget}

We derived the nitrogen budget for the entire production system for mean conditions of $28.4^{\circ} \mathrm{C}$, $\mathrm{pH} 7.14$, and alkalinity $119.0 \mathrm{mg} / \mathrm{L}$ as $\mathrm{CaCO}_{3}$. For annual production of 1300 metric tons of fish biomass, BRA administers 2210 metric tons of feeds. These amounts correspond to $6054.8 \mathrm{~kg}$ feed consumed per day and $3561.6 \mathrm{~kg}$ fish weight gain per day. Of the feed utilized, $95 \%$ (5752.0 $\mathrm{kg}$ ) was nominally $36 \%$ protein and $5 \%(302.8 \mathrm{~kg}) 40 \%$ protein content. However, laboratory analyses showed that the actual protein contents of the two feeds were somewhat lower, $35.0 \pm 0.2 \%$ and $39.8 \pm 0.2 \%$, respectively. The estimated percentages of feed types and the laboratory-determined protein concentrations were used to determine the nitrogen fixed in feed, $N_{\text {feed }}=56.38 \mathrm{~g} / \mathrm{kg}$ feed. By extrapolating $N_{\text {feed }}$, we determined a total nitrogen input of TNI $=341.381 \mathrm{~kg} /$ day.

Laboratory analyses showed that the three size-classes of fish from small to large had $18.04 \pm 0.16,20.75 \pm 0.02$ and $22.26 \pm 0.74 \%$ protein content, respectively. From these data, we determined that the nitrogen fixed in fish was $N_{\text {fish }}=33.83 \mathrm{~g} / \mathrm{kg}$ produced. Extrapolating to the daily biomass of fish produced, the total nitrogen assimilated in fish was $120.49 \mathrm{~kg} / \mathrm{day}$.

Loss of fish represented $3.5 \%$ of the total production by number, with weighing of dead fish indicating losses of 2,1 , and $0.5 \%$ from the respective size-classes. This was the equivalent of $30.6 \mathrm{~kg}$ fish/day or $1.03 \mathrm{~kg}$ total $N_{\text {mor }} /$ day, representing $0.86 \%$ of the total nitrogen assimilated. Hence, $35.3 \%$ of nitrogen from feed was assimilated in fish flesh (34.4\% harvested and $0.86 \%$ removed with mortalities), and $64.7 \%$ was unassimilated or excreted in different forms. This latter term included nitrogen in uneaten feed that we accounted for in the overall budget as 
$N_{\text {TON }}$. The nitrogen excreted, $L_{N}$, was $62.0 \mathrm{~g} / \mathrm{kg}$ fish produced. Subsequently, the cumulative daily nitrogen loading for the entire system, $L_{N}$, was $221.3 \mathrm{~kg}$.

Analyses of the effluent wastewater (estimated at $2017 \mathrm{~m}^{3} /$ day) indicated, on average, $2.88 \mathrm{mg} /$ L TAN, $1.09 \mathrm{mg} / \mathrm{L} \mathrm{NO}_{2}^{-}-\mathrm{N}, 49.3 \mathrm{mg} / \mathrm{L} \mathrm{NO}_{3}^{-}-\mathrm{N}$, and $32.05 \mathrm{mg} / \mathrm{L} \mathrm{TON}$. Extrapolated to the entire effluent volume, the overall flows were $5.8 \mathrm{~kg} \mathrm{~N} N_{\text {TAN }} /$ day (representing $1.70 \%$ of total nitrogen input, TNI), $2.2 \mathrm{~kg} N_{\mathrm{NO}_{2}} /$ day $(0.64 \% \mathrm{TNI}), 99.4 \mathrm{~kg} N_{\mathrm{NO} 3} /$ day $(29.1 \% \mathrm{TNI})$, and $64.6 \mathrm{~kg} N_{\mathrm{TON}} /$ day (18.9\% TNI). Determination of total organic nitrogen, $N_{\text {TON }}$ allowed estimation of $P_{\text {TAN }}=25.81$ $\mathrm{g} / \mathrm{kg}$ feed. The recovered fraction of dissolved inorganic nitrogen, $N_{\text {DIN }}$, resulted from the summation:

$1.70 \% N_{T A N}+0.64 \% N_{N O 2}+29.13 \% N_{N O 3}=31.47 \%$

Total nitrogen recovered, TNR, was determined as a percentage of TNI as:

$85.69 \% T N R=34.43 \% N_{\text {fish }}+0.86 \% N_{\text {mort }}+1.70 \% N_{\text {TAN }}+$

$+0.64 \% \mathrm{~N}_{\mathrm{NO} 2}+29.13 \% \mathrm{~N}_{\mathrm{NO} 3}+18.93 \% \mathrm{~N}_{\mathrm{TON}}$

We then estimated total nitrogen unaccounted for, TNUA, as $14.3 \%$ of TNI. Hence, the subsequent nitrogen mass balance for the production system was:

$341.381 \mathrm{kgTNI} /$ day $=292.529 \mathrm{kgTNR} /$ day $+48.852 \mathrm{kgTNUA} /$ day

Table 2 summarizes the daily nitrogen budget for the production system. The relatively low value of total nitrogen unaccounted for, TNUA, was presumably due to nitrogen lost as nitrogen gas produced by denitrification and as ammonia lost to volatilization. Passive denitrification was likely the primary pathway because recirculated fish culture water passed through the sedimentation basin numerous times. As discussed below, the sediment blanket and associated thick biofilm in the multi-tube clarifier created anoxic conditions favorable for microbially mediated denitrification.

\begin{tabular}{ccccccccc}
\hline \multirow{2}{*}{ Units } & \multicolumn{10}{c}{ Nitrogen pool } \\
\cline { 2 - 9 } & $\boldsymbol{T}$ & $\boldsymbol{H}_{\text {fish }}$ & $\boldsymbol{N}_{\text {mort }}$ & $\boldsymbol{N}_{\text {TAN }}$ & $\boldsymbol{N}_{\text {NO2 }}$ & $\boldsymbol{N}_{\text {NO3 }}$ & $\boldsymbol{N}_{\text {TON }}$ & TNUA \\
\hline $\mathrm{Kg}$ & 341.38 & 119.45 & 1.03 & 5.81 & 2.20 & 99.44 & 64.65 & 48.85 \\
$\%$ & 100.00 & 34.99 & 0.30 & 1.70 & 0.64 & 29.12 & 18.94 & 14.31 \\
\hline
\end{tabular}

Table 2. Daily nitrogen budget for the grow-out system at Blue Ridge Aquaculture.

\subsection{Carrying capacity, $\mathrm{RBC}$ design, $\mathrm{TAN}$ and $\mathrm{NO}_{3}^{-}-\mathrm{N}$ removal}

The carrying capacity model indicated that recirculating aquaculture systems at Blue Ridge Aquaculture could support biodegradation of up to $3.15 \mathrm{mg}$ TAN/L. This value corresponds to $0.025 \mathrm{mg} / \mathrm{L}$ maximum allowable unionized ammonia $\left(A_{\mathrm{TAN}}\right)$ at conditions of $\mathrm{pH} 7.0$ and temperature of $30^{\circ} \mathrm{C}$ (Huguenin and Colt 1989); our average values of these parameters for the four recirculating aquaculture systems monitored in greater detail were $\mathrm{pH} 7.09$ and $27.8^{\circ} \mathrm{C}$. At $0.025 \mathrm{mg} / \mathrm{L} \mathrm{TAN}$, a recirculating system should be able to receive a maximum feeding rate 
of $F R_{\max \text { TAN }}=269.8 \mathrm{~kg}$ feed/day, which would support a fish biomass of $S B M_{\max \text { TAN }}=10,287.4$ $\mathrm{kg}$ fish/system. Estimates of these parameters for each selected RAS are presented in Table 3. Comparison with actual feeding rates at the time of experiment (Table 4) showed that system loadings were 56.7 - 91.5\% of the maxima estimated (Table 3, Figure 3). Over the four tanks examined in detail, TAN removal efficiency per pass, $E_{a}$, averaged $54.4 \%$. We determined the rate of TAN production $\left(P_{\mathrm{TAN}}\right.$, Table 3$)$. We determined $P_{\mathrm{TAN}}$ per $\mathrm{kg}$ of feed consumed by dividing these values by the daily amount of feed introduced into a system: i.e., $40.6 \mathrm{~g} / \mathrm{kg}$ feed for feed with $40 \%$ crude protein content, and $36.7 \mathrm{~g} / \mathrm{kg}$ feed for feed with $36 \%$ crude protein content. We found a positive, linear relationship between $P_{\text {TAN }}$ (which also was proportional to the feeding rate) and $E_{a}$ (slope $=0.0013, r^{2}=0.72$ ), thereby showing that the rotating biological contactors efficiently removed various loadings of ammonia. None of the RBCs tested were working at maximum capacity.

\begin{tabular}{|c|c|c|c|c|c|c|}
\hline \multirow{2}{*}{ Parameter } & \multirow{2}{*}{ Units } & \multicolumn{5}{|c|}{ RAS Tested } \\
\hline & & A12 & A11 & B16 & A18 & Average \\
\hline Maximum feed rate ( $\left.F R_{\max \text { AN }}\right)$ & kg/day & 240.4 & 286.1 & 261.6 & 290.9 & 269.8 \\
\hline Maximum system biomass (SBM $\left.M_{\text {maxTAN }}\right)$ & $\mathrm{kg}$ & 4202.5 & 11443.0 & 9871.0 & 15633.0 & 10287.4 \\
\hline Actual BW as $\%$ of $S B M_{\text {maxtAN }}$ & $\%$ & 56.66 & 91.52 & 66.54 & 76.77 & 72.87 \\
\hline TAN tank concentration & $\mathrm{mg} / \mathrm{L}$ & 1.77 & 2.32 & 2.04 & 2.10 & 2.06 \\
\hline TAN conc. in RBC influent $\left(C \mathrm{TAN}_{f}\right)$ & $\mathrm{mg} / \mathrm{L}$ & 1.77 & 2.32 & 2.04 & 2.10 & 2.06 \\
\hline TAN conc. in RBC effluent $\left(C T_{A N}\right)$ & $\mathrm{mg} / \mathrm{L}$ & 0.84 & 1.01 & 0.99 & 0.90 & 0.94 \\
\hline TAN removal efficiency per pass $\left(E_{a}\right)$ & $\%$ & 52.39 & 56.47 & 51.47 & 57.28 & 54.40 \\
\hline$P_{\text {TAN }} / \mathrm{kg}$ feed & g & 40.6 & 36.7 & 36.7 & 36.7 & 37.7 \\
\hline Daily TAN production $\left(P_{\text {TAN }}\right)$ & g/day & 5522.4 & 9626.4 & 6397.9 & 8161.9 & 7427.1 \\
\hline Ammonia loading $\left(L_{\text {TAN }}\right)$ & $\mathrm{g} / \mathrm{hr}$ & 402.19 & 526.87 & 463.28 & 478.50 & 467.71 \\
\hline Ammonia removal rate $\left(R_{\text {TAN }}\right)$ & $\mathrm{g} / \mathrm{hr}$ & 210.75 & 297.50 & 238.46 & 274.11 & 255.20 \\
\hline Areal conversion rate $(A C R)$ & $\mathrm{mg}$ TAN $/ \mathrm{m}^{2}-\mathrm{d}$ & 378.4 & 534.2 & 428.2 & 429.2 & 442.5 \\
\hline$A C R$ at $S B W_{\text {maxtAN }}$ & $\mathrm{mg}$ TAN $/ \mathrm{m}^{2}-\mathrm{d}$ & 667.8 & 583.7 & 643.4 & 641.1 & 634 \\
\hline Mass TAN introduced by exchange & g/day & 39.47 & 73.10 & 50.79 & 90.93 & 63.57 \\
\hline$P_{\text {TAN }}$ introduced with water exchange & $\% /$ day & 0.71 & 0.76 & 0.79 & 1.11 & 0.84 \\
\hline *Total TAN removed by water exchange & $\% /$ day & 0.08 & 0.34 & 0.22 & 0.35 & 0.25 \\
\hline
\end{tabular}

*Daily TAN percentage removal by water exchange, assuming that exchange water is treated using the treatment train tested by Sandu (2004) with $1.60 \mathrm{mg} / \mathrm{L}$ TAN.

Table 3. Experimentally determined and predicted parameters for estimation of maximum system carrying capacity with regard to TAN for tested units. 


\begin{tabular}{lcccccc}
\hline \multirow{2}{*}{ Parameter } & Units & \multicolumn{5}{c}{ RAS Tested } \\
\cline { 3 - 7 } & & A12 & A11 & B16 & A18 & Average \\
\hline Water exchange rate & \% volume/day & 11.5 & 21.3 & 14.8 & 18.4 & 16.5 \\
Flow rate through system $(Q)$ & $\mathrm{L} / \mathrm{hr}$ & 1028.0 & 1903.7 & 1322.7 & 1645.8 & 1475.1 \\
Fish size & $\mathrm{g} /$ fish & 43 & 192 & 245 & 424 & 226 \\
Fish biomass & $\mathrm{kg}$ & 2381.0 & 10473.0 & 6568.5 & 12002.0 & 7856.1 \\
Feeding rate (FR) & $\mathrm{kg} /$ day & 136.0 & 262.0 & 174.0 & 222.3 & 198.6 \\
Feed protein content (FP) & $\%$ & 40 & 36 & 36 & 36 & 37 \\
Percent body weight fed & $\mathrm{kg}$ feed/kg fish-d & 5.72 & 2.50 & 2.65 & 1.85 & 3.18 \\
\hline
\end{tabular}

Table 4. Characteristics of the recirculating aquaculture systems selected for evaluation.

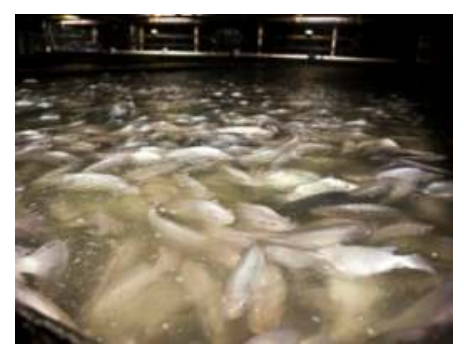

Figure 3. Towards the end of a tilapia production cycle, stocking densities approach system carrying capacity. Photograph courtesy of Blue Ridge Aquaculture.

The mass flow-rate of TAN to a rotating biological contactor, $L_{\mathrm{TAN}}$ averaged $467.7 \mathrm{~g} / \mathrm{hr}$, which was removed at an average rate of $R_{\mathrm{TAN}}=255.2 \mathrm{~g} / \mathrm{hr}$. Per-system values are presented in Table 3. The ratio of $R_{\text {TAN }}$ to $P_{\text {TAN }}$ showed that rotating biological contactors removed an average of $84.0 \%$ of total ammonia nitrogen from the selected systems. From the difference, $1.1 \%$ of TAN was recovered from exchanged water and $15.0 \%$ remained unaccounted for, probably transformed to $\mathrm{NO}_{2}^{-}-\mathrm{N}$ and $\mathrm{NO}_{3}^{-}-\mathrm{N}$ by passive nitrification or lost by volatilization of ammonia. Data in Table 3 show that fish biomass in the system was positively correlated with the percentage of total ammonia nitrogen transformed by passive nitrification (slope $=0.0015, r^{2}$ $=0.69$ ); although the correlation was not strong, it shows that systems with higher biomass had lower water quality and larger microbial populations, including nitrifiers that promoted in-situ biodegradation of ammonia.

The rotating biological contactors removed between 378.4 and $534.2 \mathrm{mg}$ TAN/m²/day $(442.5$ $\mathrm{mg} \mathrm{TAN} / \mathrm{m}^{2} /$ day on average, Table 3). The areal conversion rate, $A C R$, increased with the loading of total ammonia nitrogen. Average $A C R$ under conditions of maximum system biomass was estimated at $634.0 \mathrm{mg} \mathrm{TAN} / \mathrm{m}^{2} /$ day. We note that the difference between existing $A C R$ and predicted maximum $A C R$ is consistent with that between the existing fish biomass and predicted maximum fish biomass. 
We derived a daily nitrogen budget partitioning the total ammonia nitrogen removal from each RAS (Table 5). On average among systems, $84.0 \%$ of TAN was removed by rotating biological contactors, $14.9 \%$ by passive nitrification and ammonia volatilization, and only $1.1 \%$ was removed by periodic water exchange.

\begin{tabular}{|c|c|c|c|c|c|c|c|c|}
\hline \multirow{2}{*}{ System } & \multicolumn{2}{|c|}{${ }^{1} \mathbf{P}_{\mathrm{TAN}}$} & \multicolumn{2}{|c|}{${ }^{2} \mathrm{TAN}_{\text {pass + vol }}$} & \multicolumn{2}{|c|}{${ }^{3} \mathrm{TAN}_{\mathrm{RBC}}$ nitrification } & \multicolumn{2}{|c|}{${ }^{4} \mathrm{TAN}_{\text {exchange }}$} \\
\hline & g & $\%$ & g & $\%$ & g & $\%$ & g & $\%$ \\
\hline A12 & 5522.4 & 100 & 421.30 & 7.63 & 5057.41 & 91.58 & 43.69 & 0.79 \\
\hline A11 & 9626.4 & 100 & 2380.50 & 24.73 & 7139.90 & 74.17 & 106.00 & 1.10 \\
\hline B16 & 6397.9 & 100 & 610.22 & 9.54 & 5722.92 & 89.45 & 64.76 & 1.01 \\
\hline A18 & 8161.9 & 100 & 1463.66 & 17.93 & 6578.49 & 80.60 & 119.75 & 1.47 \\
\hline Average & 7427.2 & 100 & 1108.51 & 14.93 & 6235.09 & 83.95 & 83.55 & 1.12 \\
\hline \multicolumn{9}{|c|}{ TAN production over a 24-hour period. } \\
\hline \multicolumn{9}{|c|}{2 TAN removed by passive nitrification and by ammonia volatilization. } \\
\hline \multicolumn{9}{|c|}{${ }^{3}$ TAN removed by nitrification in $\mathrm{RBC}$. } \\
\hline \multicolumn{9}{|c|}{${ }^{4}$ TAN removed with exchanged water. } \\
\hline
\end{tabular}

Table 5. Partitioning of total ammonia nitrogen removal for each recirculating aquaculture system studied.

We conducted tests on the same recirculating aquaculture systems to determine the fate of $\mathrm{NO}_{3}{ }^{-} \mathrm{N}$ following its production by nitrification. We regarded $P_{\mathrm{NO}_{3}-\mathrm{N}}$ as approximately equal to $P_{\text {TAN }}$ by assuming that TAN lost from the systems by water exchange and volatilization was negligible. Data on $P_{\mathrm{NO}^{-}-\mathrm{N}}$, water exchange rates, and $\mathrm{NO}_{3}^{-}-\mathrm{N}$ concentrations before and after water exchange allowed us to determine the total mass of $\mathrm{NO}_{3}^{-}-\mathrm{N}$ in the systems at these times and the amounts of $\mathrm{NO}_{3}^{-}-\mathrm{N}$ lost by water exchange and passive denitrification. That is, we derived a daily mass balance quantifying $P_{\mathrm{NO}^{-}-\mathrm{N}}$ removal pathways from each RAS (Table 6). Results indicated that $\mathrm{NO}_{3}^{-}-\mathrm{N}$ accumulation was in the range of $9.1-17.2 \mathrm{mg} / \mathrm{L}$ in each $\mathrm{RAS}$ over a 24 -hour period. On average, $44.1 \%$ of $\mathrm{NO}_{3}^{-}-\mathrm{N}$ was removed by water exchange, and the difference of $55.9 \%$ was removed by passive denitrification. $\mathrm{NO}_{3}^{-}-\mathrm{N}$ in effluent could be subject to microbial denitrification if water reuse is implemented (Sandu et al. 2008).

\begin{tabular}{lcccccc}
\hline \multicolumn{1}{c}{ Parameter } & Units & \multicolumn{5}{c}{ RAS Tested } \\
\cline { 4 - 7 } & & A12 & A11 & B16 & A18 & Average \\
\hline Daily $\mathrm{NO}_{3}-\mathrm{N}$ production $\left(P_{\mathrm{NO} 3}{ }^{-}{ }_{\mathrm{N}}\right)$ & $\mathrm{g}$ & 5522.4 & 9626.4 & 6397.9 & 8161.9 & 7427.9 \\
$\mathrm{NO}_{3}-\mathrm{N}$ conc. before exchange & $\mathrm{mg} / \mathrm{L}$ & 57.3 & 57.3 & 50.9 & 49.1 & 53.6 \\
System mass $\mathrm{NO}_{3}-\mathrm{N}$ before exchange & $\mathrm{g}$ & 12290.85 & 12290.85 & 10918.05 & 10531.95 & 11507.92 \\
$\mathrm{NO}_{3}-\mathrm{N}$ conc. after exchange & $\mathrm{mg} / \mathrm{L}$ & 40.5 & 40.1 & 38.9 & 40.0 & 39.9 \\
$\mathrm{System}$ & $\mathrm{g}$ & 8687.25 & 8601.45 & 8344.05 & 7872.15 & 8376.22 \\
$\mathrm{NO}_{3}-\mathrm{N}$ and removed $\mathrm{NO}_{3}-\mathrm{N}$ after exchange & g/day & 3603.6 & 3689.4 & 2574.0 & 2659.8 & 3132.45
\end{tabular}




\begin{tabular}{|c|c|c|c|c|c|c|}
\hline \multirow{2}{*}{ Parameter } & \multirow{2}{*}{ Units } & \multicolumn{5}{|c|}{ RAS Tested } \\
\hline & & A12 & A11 & B16 & A18 & Average \\
\hline$P_{\mathrm{NO}^{-}-\mathrm{N}}^{-}$removed by exchange & $\% /$ day & 65.25 & 38.33 & 40.23 & 32.58 & 44.10 \\
\hline $\mathrm{NO}_{3}{ }^{-}-\mathrm{N}$ lost by passive denitrification & g/day & 1918.8 & 5937.0 & 3823.9 & 5502.1 & 4295.45 \\
\hline$P_{\mathrm{NO}^{-}{ }_{\mathrm{N}}}$ lost by passive denitrification & $\% /$ day & 34.75 & 61.67 & 59.77 & 67.42 & 55.90 \\
\hline
\end{tabular}

Table 6. Dynamics and partitioning of $P_{\mathrm{NO} 3-\mathrm{N}}^{-}$removal for each recirculating aquaculture system studied.

$\mathrm{NO}_{2}-\mathrm{N}$ always remained at concentrations lower than $0.3 \mathrm{mg} / \mathrm{L}$ in the fish tanks. Its concentration increased slightly as water passed through the sedimentation basin, but decreased again to concentrations lower that those in fish tanks after contact with the RBC, creating an equilibrium concentration. Because $\mathrm{NO}_{2}^{-}-\mathrm{N}$ concentrations were generally stable and below levels considered a threat to fish, we pursued no further determination of $\mathrm{NO}_{2}-\mathrm{N}$ dynamics.

\section{Discussion}

We quantified nitrogen fixation and biodegradation through the recirculating tilapia production system at Blue Ridge Aquaculture, a large commercial production facility. The $34.4 \%$ of total nitrogen input assimilated by the fish indicated excellent nitrogen utilization relative to other production systems. For example, Suresh and Kwei (1992) found that less than $20 \%$ of nitrogen was assimilated by tilapia using feed with $22 \%$ crude protein content and much lower fish stocking densities than those at BRA. Using feed with 34\% crude protein content, Siddiqui and Al-Harbi (1999) reported 21.4\% nitrogen assimilation by red tilapia. Although Suresh and Kwei (1992) found decreasing nitrogen assimilation with increasing fish density, Refstie (1977), Rakcocy and Allison (1981), and Vijayan and Leatherland (1988) reported the opposite finding. We attribute the high nitrogen assimilation in our study to higher protein content in feeds used at BRA, well-managed water quality, and to production of selectively bred fish (Hallerman 2000). Also, most earlier studies reported higher mortality rates, diminishing total nitrogen accumulated in fish.

The small amounts of nitrogen recovered as TAN and $\mathrm{NO}_{2}^{-}-\mathrm{N}$ likely were due to biodegradation in rotating biological contactors, which oxidized them effectively to $\mathrm{NO}_{3}{ }^{-}-\mathrm{N}$. Most of the nitrogen recovered as total organic nitrogen $(18.93 \%)$ was probably due to feces, noting that feed was consumed by fish almost instantly at distribution, and that only fine particulates could escape as wasted feed. Assuming that some organic nitrogen in feces dissolved upon contact with water, our results with tilapia, which accounted for nitrogen from the entire organic pool, broadly agree with those of Porter et al. (1987, who found $10 \%$ fecal nitrogen) and Thoman et al. (2001, who recovered 14\% nitrogen from suspended solids) for other species.

For total nitrogen unaccounted for $(14.31 \%)$, removal of $\mathrm{N}_{2}$ gas through passive denitrification is the most reasonable explanation. Although denitrification may seem surprising given the relatively high dissolved oxygen in the recirculating systems, development of anoxic microsites in sediment provides likely sites for denitrification (Brandes and Devol 1997). Anoxic 
microsites could arise in fish tanks where particles accumulated, or more likely, in the sedimentation basin, where a blanket of sediments developed for 19-36 hours before removal. We observed that large amounts of gases rapidly collected beneath the water surface in the sedimentation basin; however, samples we collected were contaminated with oxygen, precluding evaluation of biologically-generated nitrogen production. A thick biofilm on the tanks' walls also could have provided anoxic microsites, contributing to $\mathrm{NO}_{3}^{-}-\mathrm{N}$ removal. This explanation was supported by our results for Tank A12, where fish were harvested and the biofilm removed from the walls less than two weeks before our monitoring began. The time for regrowth of the biofilm to a thickness that could allow denitrification was limited. Subsequently, less than $35 \%$ of $\mathrm{NO}_{3}^{-}-\mathrm{N}$ production was removed by passive denitrification from this particular system, considerably less than in the other three systems monitored. In-situ denitrification has been reported by other authors. For example, Bovendeur et al. (1987) found that $40-80 \%$ of TAN oxidized by nitrification then was reduced by denitrification. Thoman et al. (2001) attributed $9-21 \%$ losses of systems' nitrogen to denitrification. The $56 \%$ removal of $\mathrm{NO}_{3}^{-}-\mathrm{N}$ by passive denitrification in our study represented an important, positive outcome, because it could reduce by more than half the investment necessary for nitrogen removal should the effluent be treated and reused as suggested by Sandu et al. $(2008,2011)$.

Our results indicated that despite high fish densities maintained at BRA, the systems are not being operated at their maximum carrying capacity. Our results showed that an average of $73 \%$ of the recirculating systems' productive potential was utilized, although utilization approached $92 \%$ in systems holding fish close to harvest size. In particular, much productive potential can be realized in systems holding smaller fish for long periods. By better distributing fish biomass among systems via more frequent grading, net production could be increased within existing space. Our suggestion for increased production is supported by the excellent average removal efficiency for rotating biological contactors $(54.4 \%)$ at a recirculation rate of almost one pass per hour, and by an average areal conversion rate of $442.5 \mathrm{mg} \mathrm{TAN} / \mathrm{m}^{2} / \mathrm{day}$, which maintained an average TAN of $2.06 \mathrm{mg} / \mathrm{L}$ in fish tanks. Up to $2830 \mathrm{mg} \mathrm{TAN} / \mathrm{m}^{2} /$ day can be removed by a rotating biological contactor (Rogers and Klemeston 1985), suggesting that the biofilters could function successfully under the maximum conditions of $3.15 \mathrm{mg} / \mathrm{L}$ TAN and $634 \mathrm{mg} \mathrm{TAN} / \mathrm{m}^{2} /$ day areal conversion rate that we predicted. Additionally, reusing water using a treatment train such as that described by Sandu $(2004)$ and Sandu et al. $(2008,2011)$ with $1.6 \mathrm{mg} / \mathrm{L}$ TAN, only $0.84 \%$ of total ammonia nitrogen produced would be reintroduced to the recirculating systems. This additional loading would be removed easily by the rotating biological contactors, without significant increase of TAN throughout the systems.

\section{Conclusion}

Routine aquaculture production generates waste products for which controlled biodegradation in treatment units is a major consideration in design and operation of recirculating aquaculture systems. Biodegradation of nitrogenous wastes is critical, especially for unionized ammonia and nitrite, which are toxic to fish. We quantified the dynamics of nitrogen through a large commercial recirculating aquaculture facility producing hybrid tilapia Oreochromis sp. Our nitrogen budget evaluated total ammonia nitrogen (TAN) production and 
removal in biofilters, quantifying the fate of nitrate-nitrogen $\left(\mathrm{NO}_{3}^{-}-\mathrm{N}\right)$ and determining the systems' maximum carrying capacity under steady-state conditions. Most of the recovered nitrogen was in fish, nitrate-nitrogen, and total organic nitrogen pools, with relatively small proportions as total ammonia nitrogen, mortalities, and nitrite-nitrogen, totaling $86 \%$. The remaining $14 \%$ of the nitrogen budget unaccounted for likely was lost by passive denitrification to nitrogen gas and by volatilization of ammonia. Our nitrogen biodegradation model predicts that the systems could operate safely at up to $3.15 \mathrm{mg} / \mathrm{L}$ total ammonia nitrogen. Under current production conditions, system loading was $57-92 \%$ of the maximum fish biomass that could be supported. The biofilters' areal conversion rate could be increased by half under conditions of maximum biomass loading. $\mathrm{NO}_{2}^{-}-\mathrm{N}$ was not a parameter of concern, always remaining below $0.3 \mathrm{mg} / \mathrm{L}$. Our results showed that microbial biodegradation of fish wastes was more than adequate and that fish production could be increased within the existing farm infrastructure, especially by more frequent grading of fish in order to stock production systems at densities approaching carrying capacity. With denitrification, discharged culture water could be reused to realize savings in operating costs. Beyond the narrow interest in our study system, our approach can be applied more broadly to other fish culture systems.

\section{Acknowledgements}

We are grateful for the support of the Commercial Fish and Shellfish Technologies program and the Department of Fish and Wildlife Conservation at Virginia Tech University. Blue Ridge Aquaculture graciously allowed access to facilities and production records. Julie Petruska trained S.S. water quality testing procedures. The expertise of Nancy Love was indispensable in experimental design and analysis.

\section{Author details}

\section{S. Sandu and E. Hallerman*}

*Address all correspondence to: ehallerm@vt.edu

Department of Fish and Wildlife Conservation, Virginia Polytechnic Institute and State University, Blacksburg, VA, USA

\section{References}

[1] Acosta-Nassar, M.V.; Morrell, J.M., \& Corredor, J.E. (1994). The nitrogen budget of a tropical semi-intensive freshwater fish culture pond. Journal of the World Aquaculture Society, Vol. 25, No. 2, pp. 261-270, ISSN 0893-8849 
[2] Atwood, H.L.; Fontenot, Q.C., Tomasso, J.R., \& Isely, J.J. (2001). Toxicity of nitrite to Nile tilapia: effect of fish size and environmental chloride. North American Journal of Aquaculture, Vol. 63, No. 1, pp. 49-51, ISSN 1522-2055

[3] APHA (American Public Health Association), American Water Works Association \& Water Environment Federation (1998). Standard Methods for the Examination of Water and Wastewater, $20^{\text {th }}$ edition. American Public Health Association, ISBN 0-875530235-7, Washington, DC

[4] Benli, A.C.K.; Koksal, G., \& Ozkul, A. (2008). Sublethal ammonia exposure of Nile tilapia (Oreochromis niloticus L.): effects on gill, liver, and kidney histology. Chemosphere, Vol. 72, No. 9, pp. 1355-1358, ISSN 0045-6535

[5] Bovendeur, J.; Eding, E.H., \& Henken, A.M. (1987). Design and performance of a water recirculation system for high-density culture of the African catfish, Clarias gariepinus (Burchell 1822). Aquaculture, Vol. 63, No. 1-4, pp. 329-353, ISSN 0044-8486

[6] Brandes, J.A. \& Devol, A.H. (1997). Isotopic fractionation of oxygen and nitrogen in coastal marine sediments. Geochimical et Cosmochimical Acta, Vol. 61, pp. 1798-1801, ISSN 0016-7037

[7] Chen, S.; Ling, J., \& Blancheton, J. (2007). Nitrification kinetics of biofilm as affected by water quality factors. Aquacultural Engineering, Vol. 34, No 3, pp.179-197, ISSN 0144-8609

[8] Colt, J. (2006). Water quality requirements for reuse systems. Aquacultural Engineering, Vol. 34, No. 3, pp. 143-156, ISSN 0144-8609

[9] Costa-Pierce, B.A. \& Rakocy, J.E. eds. (1997). Tilapia Aquaculture in the Americas. World Aquaculture Society, Baton Rouge, LA. 522 pp. in two volumes, ISBN 1-88807-01-6 and 1-88897-04-0

[10] Crab, R.; Avnimelech, Y., Defoird, T., Bossier, P., \& Verstraete, W. (2007). Nitrogen removal techniques in aquaculture for sustainable production. Aquaculture, Vol. 270, No. 1-4, pp. 1-14, ISSN 0044-8486

[11] Daud, S.K.; Hasbollah, D., \& Law, A.T. (1988). Effects of unionized ammonia on red tilapia (Oreochromis mossambicus/O. niloticus hybrid) fry. Pages 411-413 in Pullin, R.S.V., Bhukaswan, T., Tonguthai, K., and Maclean, J.L. The Second International Symposium on Tilapia in Aquaculture. ICLARM Conference Proceedings 15. Thailand Department of Fisheries and International Center for Living Aquatic Resources Management, ISBN 971-1022-58-3, Manila

[12] Diaz, V.; Ibanez, R., Gomez, P., Urtiaga, A.M., \& Ortiz, I. (2012). Kinetics of nitrogen compounds in a commercial marine recirculating aquaculture system. Aquacultural Engineering, Vol. 50, No. 1, pp. 20-37, ISSN 0144-8609

[13] El-Sherif, M.S.; \& El-Feky-A.M. (2008) Effect of ammonia on Nile tilapia (O. niloticus) performance and some hematological and histological measures. $8^{\text {th }}$ International 
Symposium on Tilapia in Aquaculture, Cairo, Egypt, October 12-14, 2008, http://ag.arizona.edu/azaqua/ista/ISTA8/FinalPapers/PDF\%20Files/39\%20mohamed \%20shreif12.pdf

[14] Eshchar, M.; Lahav, O., Mozes, N., Peduel, A, \& Ron, B., (2006). Intensive fish culture at high ammonium and low pH. Aquaculture, Vol. 255, No. 1-4, pp. 301-313, ISSN 0044-8486

[15] Evans, J.J.; Pasnik, D.J., Brill, G.C., \& Klesius, P.H. (2006) Un-ionized ammonia exposure in Nile tilapia: toxicity, stress response, and susceptibility to Streptococcus agalactiae. North American Journal of Aquaculture, Vol. 68, No. 1, pp. 23-33, ISSN 1522-2055

[16] Fitzsimmons, K., ed. (1997). Tilapia aquaculture: Proceedings from the Fourth International Symposium on Tilapia in Aquaculture. Natural Resource, Agriculture, and Engineering Service, Cooperative Extension, 152 Riley-Robb Hall, Ithaca, NY. 808 pp. in two volumes, ISBN 0-935817-58-1

[17] Hallerman, E.M. (2000). Genetic improvement of fishes for commercial recirculating aquaculture systems: a case study involving tilapia. In Libey, G.S. \& Timmons, M.B., eds. Proceedings of the Third International Conference on Recirculating Aquaculture, Roanoke, VA, July 20-23, 2000.

[18] Hamlin, H.J.; Michaels, J.T., Beaulaton, C.M., Graham, W.F., Dutt, W., Steinbach, P., Losordo, T.M., Schrader, K.K., and Main, K.L. (2008). Comparing denitrification rates and carbon sources in commercial upflow denitrification biological filters in aquaculture. Aquacultural Engineering, Vol. 38, No. 2, pp. 79-92, ISSN 0144-8609

[19] Huguenin, J.E. \& Colt, J. (1989). Design and operating guide for aquaculture seawater systems. Elsevier Interscience, ISBN 0-444-50577-6, Amsterdam. 264 pp

[20] Itoi, S.; Ebihara, N., Washio, S, and Sugita, H. (2007). Nitrate-oxidizing bacteria, Nitrospira, distribution in the outer layer of the biofilm from filter materials of a recirculating water system for the goldfish Carassius auratus. Aquaculture, Vol. 264, No. 1-4, pp. 297-308, ISSN 0044-8486

[21] Krom, M.D. \& Neori, A. (1989). A total nitrogen budget for an experimental intensive fishpond with circularly moving seawater. Aquaculture, Vol. 83, No. 1-2, pp. 345-358, ISSN 0044-8486

[22] Krom, M.D.; Porter, C., \& Gordin, H. (1985). Nutrient budget of a marine fish pond in Eilat, Israel. Aquaculture, Vol. 51, No. 1, pp 65-80, ISSN 0044-8486

[23] Lekang, O.I. (2007). Ammonia removal. Chapter 9 in Aquaculture Engineering. Blackwell Publishing, ISBN 978-1-4051-2610-6, Oxford

[24] Lemarie, G.; Dosdat, A., Coves, D., Dutto, G., Gasset, E., \& Person-Le Ruyet, J. (2004). Effect of chronic ammonia exposure on growth of European seabass (Dicentrarchus labrax) juveniles. Aquaculture, Vol. 229, No. 1-4, pp. 479-491, ISSN 0044-8486 
[25] Lim, C. \& Webster, C.D., eds. (2006). Tilapia Biology, Culture, and Nutrition. The Haworth Press, Binghamton, New York, NY, USA, ISBN 13: 978-1-56022-318-4

[26] Losordo, T.M. (1997). Tilapia culture in intensive recirculating systems. Pages 185-211 in Costa-Pierce, B.A. \& Rakocy, J.E. Tilapia Aquaculture in the Americas, volume 1. World Aquaculture Society, ISBN 1-88807-01-6, Baton Rouge, Louisiana, USA

[27] Losordo, T.M., and Westerman, P.W. (1994). An analysis of the biological, economic, and engineering factors affecting the cost of fish production in recirculating aquaculture systems. Journal of the World Aquaculture Society Vol. 25, No. 2, pp. 193-203. ISSN 1749-7345

[28] Losordo, T.M. \& Westers, H. (1994). System carrying capacity and flow estimation. In: M.B. Timmons \& T.M. Losordo, editors. Aquaculture water reuse system: Engineering design and management. Developments in Aquaculture and Fisheries Sciences, vol. 27. Elsevier Science, ISBN 9780444895851, Amsterdam. Pp. 9-60

[29] Palacheck, R.M. \& Tomasso, J.R. (1984). Toxicity of nitrite to channel catfish (Ictalurus punctatus), tilapia (Tilapia aurea), and largemouth bass (Micropterus salmoides): evidence for a nitrite exclusion mechanism. Canadian Journal of Fisheries and Aquatic Sciences Vol. 41, No. 12, pp. 1739-1744, ISSN 1205-7533

[30] Porter, C.B.; Krom, M.D., Robbins, M.G., Brickell, L., \& Davidson, A. (1987). Ammonia excretion and total $\mathrm{N}$ budget for gilthead seabream (Sparus aurata) and its effect on water quality conditions. Aquaculture, Vol. 66, No. 3-4, pp. 287-297, ISSN 0044-8486

[31] Refstie, T. (1977). Effects of density on growth and survival of rainbow trout. Aquaculture, Vol. 10, No. 3, pp. 231-242, ISSN 0044-8486

[32] Racocy, J. \& Allison, R. (1981). Evaluation of a closed recirculating system for the culture of tilapia and aquatic macrophytes. In: Fish Culture Section, Bioengineering Symposium for Fish Culture, American Fisheries Society, Bethesda, Maryland, USA, Pages 296-307

[33] Redner, B.D. \& Stickney, R.R. (1979). Acclimation to ammonia by Tilapia aurea. Transactions of the American Fisheries Society Vol. 108, No. 4, pp. 383-388, ISSN 1548-8659

[34] Rogers, G.L. \& Klemetson, S.L. (1985). Ammonia removal in selected aquaculture water reuse biofilters. Aquacultural Engineering, Vol. 4, No. 2, pp. 135-154, ISSN 0144-8609

[35] Russo, R.C. \& Thurston, R.V. (1991). Toxicity of ammonia, nitrite and nitrate to fishes. Pages 58-89 in D.E. Brune and J.R. Tomasso, eds. Aquaculture and water quality. Advances in World Aquaculture 3. World Aquaculture Society, Baton Rouge, Louisiana, USA. 
[36] Sandu, S.I. (2004). Evaluation of ozone treatment, pilot-scale wastewater treatment plant, and nitrogen budget for Blue Ridge Aquaculture. Ph.D. dissertation, Virginia Polytechnic Institute and State University, Blacksburg, Virginia, USA.

[37] Sandu, S.; Brazil, B., \& Hallerman, E. (2008). Efficacy of a pilot-scale wastewater treatment plant upon a commercial aquaculture effluent: I. Solids and carbonaceous compounds. Aquacultural Engineering, Vol. 39, No. 1, pp. 78-90, ISSN 0144-8609

[38] Sandu, S.; Brazil, B., \& Hallerman, E. (2011). Efficacy of pilot-scale wastewater treatment upon a commercial recirculating aquaculture facility effluent. Pages 141-158 in B. Sladonja, ed. Aquaculture and the Environment: A Shared Destiny. Intech. ISBN 978-953-307-749-9, Rijeka, Croatia.

[39] Schreier, H.J.; Mirzoyan, N., \& Saito, K. (2010). Microbial diversity of biological filters in recirculating aquaculture. Current Opinion in Biotechnology, Vol. 21, No. 3, pp. 318-325, ISSN 0958-1669

[40] Siddiqui, A.Q. \& Al-Harbi, A.H. (1999). Nutrient budget in tanks with different stocking densities of hybrid tilapia. Aquaculture, Vol. 170, No. 3-4, pp. 245-252, ISSN 0044-8486

[41] Suresh, A.V. \& Kwei, L.C. (1992). Effect of stocking density on water quality and production of red tilapia in a recirculating water system. Aquacultural Engineering, Vol. 11, No. 1, pp. 1-22, ISSN 0144-8609

[42] Svobodova, Z.; Machova, J., Poleszczuk, G., Huda, J., Hamackova, J., \& Kroupova, H. (2005). Nitrite poisoning of fish in aquaculture facilities with water-recirculating systems. Acta Veterinaria Brno, Vol. 74, pp. 129-137, ISSN 0001-7213

[43] Tal, Y.; Watts, J.E.M., and Schreier, H.J. (2006). Anaerobic ammonium-oxidizing (annamox) bacteria in associated activity in fixed-film biofilters of a marine recirculating aquaculture system. Applied and Environmental Microbiology, Vol. 72, No. 4, pp. 2896-2904, ISSN 0099-2240

[44] Tchobanoglous, G. \& Schoeder, E.D. (1985). Water Quality: Characterization, Modeling, Modification. Addison-Wesley Publishing Company. ISBN: 10-0201054337, Reading, MA

[45] Thiex, N.J.; Manson, H., Anderson, S., \& Persson, J. A. (2002). Determination of crude protein in animal feed, forage, grain, and oilseeds by using block digestion with a copper catalyst and steam distillation into boric acid: collaborative study. Journal of the Association of Official Agricultural Chemists, Vol. 85, pp. 309-317, ISSN 0095-9111

[46] Thoman, E.S.; Ingall, E.D., Davis, D.A., \& Arnold, C.R. (2001). A nitrogen budget for a closed, recirculating mariculture system. Aquacultural Engineering, Vol. 24, No. 3, pp. 195-211, ISSN 0144-8609

[47] van Kessel, M.A.J.H.; Harhangi, H.R., van de Pas-Schoonen, K., van de Vossenberg, J., Flik, G., Jetten, M.S.M., Klaren, P.H.M., \& Op den Camp, H.J.M. (2010). Biodiversi- 
ty of N-cycle bacteria in nitrogen removing bed biofilters for freshwater recirculating aquaculture systems. Aquaculture, Vol. 306, No. 1-4, pp. 177-184, ISSN 0044-8486

[48] van Rijn, J. (1996). The potential for integrated biological treatment systems in recirculating fish culture: A review. Aquaculture Vol. 139, No. 3-4, pp. 181-201, ISSN 0044-8486

[49] Vijayan, M.M. \& Leatherland, J.F. (1988). Effects of stocking density on the growth and stress response in brook charr Salvelinus fontinalis. Aquaculture, Vol. 75, No. 1-2, pp. 159-170, ISSN 0044-8486

[50] Wang, Y.; Zhang, W., Li, W., \& Xu, Z. (2006). Acute toxicity of nitrite on tilapia (Oreochromis niloticus) at different external chloride concentrations. Fish Physiology and Biochemistry, Vol. 32, No. 1, pp. 49-54, ISSN 0920-1742

[51] Yildiz, H.Y.; Koksal, G., Borazan, G., \& Benli, C.K. (2006). Nitrite-induced methemoglobinemia in Nile tilapia, Oreochromis niloticus. Journal of Applied Ichthyology, Vol. 22, No. 5, pp. 427-426, ISSN 1439-0426 
